\title{
Supplication Leader Impression Management Strategy and Organizational Citizenship Behaviour of Tertiary Institutions in Port Harcourt, Nigeria
}

\author{
OSHO, Olayinka Kayode \\ Department of Management, Faculty of Management Science, Rivers State University, Port Harcourt \\ GABRIEL, J. M. O. PhD \\ Department of Management, Faculty of Management Science, Rivers State University, Port Harcourt \\ KONYA, K. T. PhD \\ Department of Management, Faculty of Management Science, Rivers State University, Port Harcourt
}

\begin{abstract}
This is an expository study on leader impression management strategy and organizational citizenship behaviour of tertiary institutions in Port Harcourt, Nigeria. The purpose is to investigate the relationship between supplication leader impression management strategy and organizational citizenship behaviour. The objective is to determine how supplication as a dimension of leader impression management strategy influences the measures of organizational citizenship behaviour of tertiary institutions in Port Harcourt, Nigeria. The research design adopted for the study was cross-sectional survey. The population is composed of a total of 4000 non-academic staff of 4 tertiary institutions in Port Harcourt. The sampling procedure and sample size determination formula used for the study is the Krejcie \& Morgan table. The validity was obtained through peer to peer and professional vetting, while the reliability test was based on the Cronbach alpha reliability test. The Spearman's Rank Order Correlation Coefficient was the statistical tool; aided by the Statistical Package for the Social Sciences (SPSS). The study found that leader impression management strategy significantly contributes to the achievement of organizational citizenship behaviour in tertiary institutions in Port Harcourt. The study recommends that the use of supplication strategy by leaders should be such that appeals to the interest and benefits of the subordinates and not as reveals the leader as weak or incapable.
\end{abstract}

Keywords: Impression Management, Supplication, Organizational Citizenship Behaviour.

DOI: $10.7176 / \mathrm{EJBM} / 11-32-09$

Publication date: November $30^{\text {th }} 2019$

\section{Introduction}

Research on organizations has long been concerned with the role of management and the attitudes of workers towards their jobs, as well as what these workers are willing to dedicate to and offer the organization (Dorothea, 2012). One resultant attitude workers can apply at work is organisational citizenship behaviour (OCB). Previous studies (Cohen \& Vigoda, 2000; Ertürk, 2007) revealed that organizational citizenship behaviours (OCB) are imperative for the interpersonal relationships at work, and are required for the success of organisations, including its resilient tendencies (Gabriel, 2015). Miller (2002) averred that a person who engages in OCB might receive appreciation and recognition which could enhance the likelihood of repeating the OCB behaviour.

Past studies (Shokrkon \& Naami, 2009; Erturk, 2007) agreed that organizational citizenship behaviour is one of the important outcomes of workers perception and relationships with their superiors. Leader-follower relationship and exchange has been identified as a major requirement for tertiary institutions which aim to achieve excellence in their operations. This relationship affects the extent to which a worker is content with the rewards he or she derives from his or her job, particularly in terms of intrinsic motivation. Smith et al. (2009) opined that the perception subordinates have of their leader affects their level of trust and commitment to the organization.

Despite the growing interest and focus of research in OCB, most studies unfortunately has focused on a limited range of possible antecedents or predictors of the variable. For instance, Organ and Ryan (cited in Bhavnagar, 2005) conducted a meta-analytic review of 55 studies of OCB. Their study concentrated on job attitudes such as fairness, organisational commitment, employee engagement, leadership consideration and personality as predictor variables of OCB. Some studies have concluded that one aspect of job attitude, job satisfaction, is a good predictor of employee performance and organizational citizenship behaviour. Unfortunately, industrial and organisational studies have not provided any strong theoretical or empirical evidence to support a leader supplication strategy-citizenship relationship. Although leader impression management has been examined by previous studies interested in task performance (Bhavnagar, 2005), little is known about how supplication as a dimension of leader impression management strategy would influence 
organizational citizenship behaviour.

The purpose of this study is thus to examine the association of supplication leader impression management strategy on organizational citizenship behaviour of tertiary institutions in Port Harcourt. The objectives of this study therefore are as follows:

i. To examine the relationship between leaders' supplication strategy and employee Altruism of tertiary institutions in Port Harcourt.

ii. To examine the relationship between leaders' supplication strategy and employee sportsmanship of tertiary institutions in Port Harcourt.

iii. To examine the relationship between leaders' supplication strategy and employee conscientiousness of tertiary institutions in Port Harcourt.

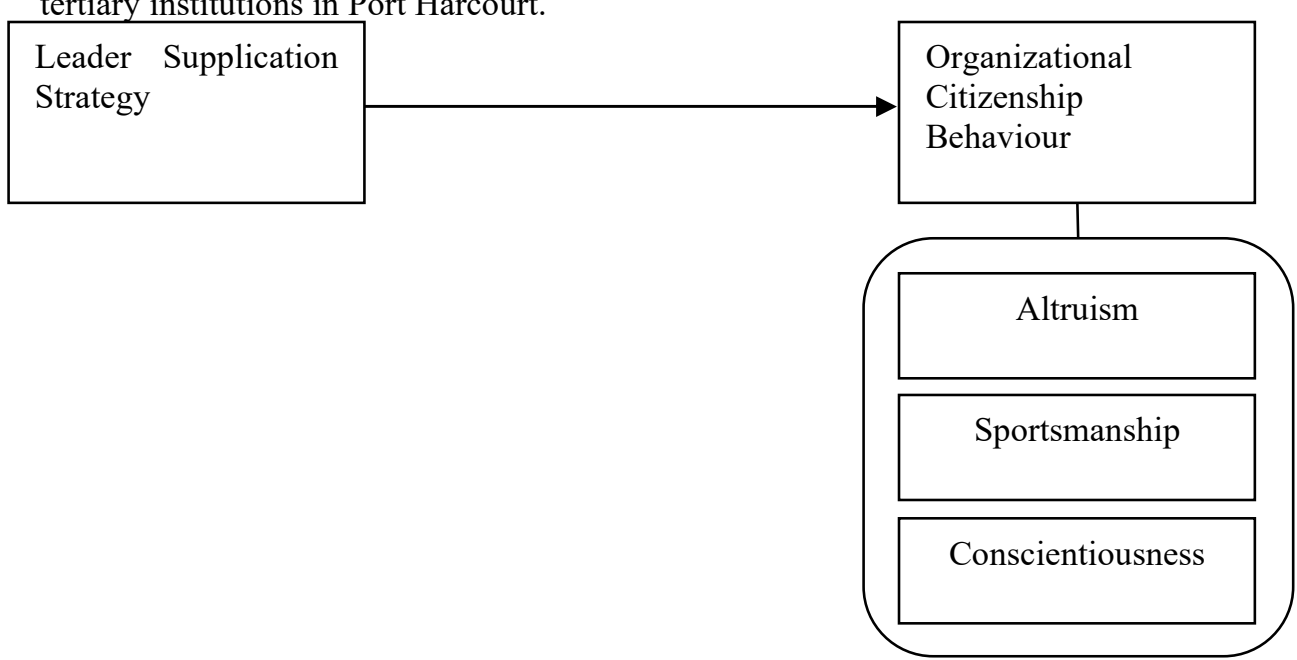

Figure 1. Conceptual framework for the Study

Source: Researcher's desk, 2019; dimensions for leader impression management adapted from Kleinmann and Klehe (2011); measures for OCB adapted from Organ et al (2006).

The following research questions are to be answered in the course of this study. They are as follows:

i. To what extent does leader supplication strategy influence employee's altruism of tertiary institutions in Port Harcourt?

ii. To what extent does leader supplication strategy influence employee's sportsmanship of tertiary institutions in Port Harcourt?

iii. To what extent does leader supplication strategy influence employee's conscientiousness of tertiary institutions in Port Harcourt?

\section{Literature}

\section{Theoretical Foundation}

The relationship between supplication leader impression management strategy and organizational citizenship behaviour is one which dwells primarily on the nature of the exchange that occurs between these parties in the context of the organization. Consequently, in addressing this relationship (supplication leader impression management strategy and organizational citizenship behaviour), the leader-member exchange theory becomes a relevant theoretical framework (see Dirks \& Ferrin, 2002). Leader-member exchange theory is based on the assumption that leaders establish a social exchange relationship with their employees and that the nature of this exchange relationship influences the manner in which the leader treats each individual employee. High quality exchange relationship involves mutual trust, support, and loyalty between the leader and his or hers subordinates; and triggers an enhanced levels of interpersonal attraction and bidirectional influence. Wang, Law and Hackett (2005) claim that the leader-member exchange (LMX) and Organizational Citizenship Behaviour (OCB) have become the foundation of a new era of managing a diversified workforce in the advent of a globalized business world.

\section{Leader Impression Management Strategy}

When individuals find themselves in situations where they want to present themselves as competent, they are likely to convey self-promoting messages that emphasize relevant personal attributes and achievements; corresponding to what expectations they think others have of a competent person in this position. Sometimes this might also involve the use of impressions which they assume would help or facilitate the achievement of their objectives (Ellis \& Wittenbaum, 2000). Impression management is the process by which people seek to influence the images others perceive or form of them (Parker \& Berger, 2004). Impression management is an attempt by 
individuals to control the image they project in social interaction. It is a standard element of organizational life, employed to influence the outcomes of processes such as job interviews, work relationships, appraisals, promotion decisions and role expectations (Sandberg \& Pinnington, 2009; Porter \& Nohria, 2010). Impression management is a multi-dimensional construct having supplication as one of such dimensions.

\title{
Supplication Strategy
}

This dimension of leader impression management is known as a "last resort" strategy (Van Iddekinge et al, 2007). Leaders use this strategy when they want to gain sympathy from their subordinates. They reveal their inadequacies or they tend to underestimate themselves. They behave in a humble manner and they demean themselves. Jones (1990) describes this strategy as "bending over backwards in acknowledging inadequacies, flaws and weaknesses". In this dimension, leaders try to elicit the sympathy of the subordinate without causing irremediable harm to their reputation (Van Iddekinge et al, 2007). Generally speaking, supplication is when a leader advertises his or her weakness or shortcomings in order to elicit an attribution of being needy from subordinates.

\section{Organisational Citizenship Behaviour (OCB)}

Organizational citizenship behavior (OCB) is a set of discretionary workplace behaviors that exceed one's basic job requirements or transcends one's job description. These behaviours are often described as going beyond one's call of duty to act in ways that are not directly rewarded, but advantageous to the organization. Research on OCB has been extensive since its introduction several years ago (Zarea, 2012). The dimension of OCB are multiple but some are examined here.

\begin{abstract}
Altruism
This dimension includes all discretionary behaviours that have the effect of helping others with organizationally relevant tasks or problems. Altruism in simple words means being helpful, helping or helpfulness (Organ, et al, 2006). It implies offering assistance to other members of the organization in their tasks. This could comprise behaviours such as voluntarily helping new employees, helping co-workers who are overloaded, assisting workers who were absent, guiding co-workers to accomplish difficult tasks (Smith, et al 2009). Organ, et al (2006) defined altruism as voluntary behaviours wherein an employee provides assistance to an individual with a particular problem to complete his or her task under unusual circumstances. Altruism refers to a member helping other members of the organization in their work. Podsakoff et al. (2000) has demonstrated that altruism is significantly related to workers' performance and enhances productivity.

\section{Sportsmanship}

This dimension of organizational citizenship behaviour entails an avoidance of negative behaviour such as complaining, and petty grievances etc. It means accepting less than minimal circumstances with ease and not discussing it with outsiders. Sportsmanship is defined as a willingness to tolerate the inevitable inconveniences and impositions of work without complaining. (Organ et al, 2006). It refers to the individual's desire not to complain when experiencing the inevitable inconveniences and discomfort generated in exercising a professional activity. Sportsmanship refers to the expression of control and a good disposition in the face of difficulties in the workplace, being positive and tolerant towards problems experienced in the workplace.
\end{abstract}

\section{Conscientiousness}

This refers to organization members carrying out their role requirements far beyond the minimum requirement or expectation such as being punctual, not taking extra breaks, doing one's duties sincerely even when no one is watching and maintaining and conserving resources. Conscientiousness is a discretionary behaviour that goes well beyond the minimum role requirement level of the organization, such as obeying rules and regulations, not taking extra breaks, working extra-long days (Marchington, 2001). Conscientiousness is a prototype of going well beyond minimally required levels of attendance, punctuality, and housekeeping, penchant towards conserving resources, and overall giving an impression of being a responsible citizen of the organization. If the employee is highly conscientious it implies that he is highly responsible and needs less supervision (Burke et al, 2007). Altruism and conscientiousness are the two major or overarching dimensions of OCB (Aziri, 2008).

\section{Supplication and Organizational Citizenship Behaviour}

Jones (1990) describes supplication as the last resort strategy. Leaders in conversations perform supplication to gain sympathy from their subordinates by disclosing shortcomings or undervaluing themselves through modesty. More often, this impression management strategy tends to be used successfully by actors with less power within relationships, and particularly when a leader's competency is called into question. Leaders who undertake this strategy will behave in a humble manner and belittle or undervalue themselves. 
Supplication works by triggering a powerful social rule known as the norm of social responsibility that says we should help those who are in need (Rosenfeld et al., 1995). The success of employing this impression management strategy rests with the leader's ability to admit to an inadequacy while still appearing capable, to let modesty reflect the secure acceptance of a few weaknesses that are obviously trivial in the context of one's strengths (Jones, 1990).

The relationship between leaders' supplication strategy and organizational citizenship behaviour is to be empirically assessed based on the tests for the following hypothetical statements:

$\mathrm{H}_{\mathrm{O} 1}$ : There is no significant relationship between leaders' supplication strategy and employees' altruism of tertiary institutions in Port Harcourt.

$\mathrm{H}_{\mathrm{O} 2}$ : There is no significant relationship between leaders' supplication strategy and employees' sportsmanship of tertiary institutions in Port Harcourt.

$\mathrm{H}_{\mathrm{O} 3}$ : There is no significant relationship between leaders' supplication strategy and employees' conscientiousness of tertiary institutions in Port Harcourt.

\section{Methodology}

The research design adopted for the study is cross-sectional survey design. The population for this study comprised a total of 4000 non-academic staff of Government owned tertiary institutions in Rivers State comprising Captain Elechi Amadi Polytechnic, Ignatius Ajuru University of Education, Rivers State University and University of Port Harcourt. The Krejcie \& Morgan table was used to derive a sample size of 351 of the respondents. Data was collected through structured questionnaire. The research instrument was subjected to professional opinions and approval by the supervisors. To ensure the reliability of the survey instrument in this study the Cronbach alpha reliability test was carried out on the generated data. The Spearman's Rank Order Correlation Coefficient was used as statistical instrument.

\section{Data Analysis and Result}

A total of 351 copies were distributed based on the adopted sample size, only 288 copies representing $82 \%$ of the distributed copies were successfully retrieved within the specified timeframe apportioned for questionnaire completion. However, after cleaning and error assessment, only 273 questionnaire copies comprising $78 \%$ of the total number were included and utilized as valid cases for the assessment in the study of the variables.

$\mathrm{H}_{\mathrm{O} 1}$ : There is no significant relationship between supplication and altruism in tertiary institutions in Port Harcourt.

$\mathrm{H}_{\mathrm{O} 2}$ : There is no significant relationship between supplication and sportsmanship in tertiary institutions in Port Harcourt.

$\mathrm{H}_{\mathrm{O} 3}$ : There is no significant relationship between supplication and conscientiousness in tertiary institutions in Port Harcourt.

Table 1. Supplication and the measures of organizational citizenship behaviour

\begin{tabular}{|c|c|c|c|c|c|c|}
\hline & & & Supplication & Altruism & Sportsman & Conscient \\
\hline \multirow{12}{*}{$\begin{array}{l}\text { Spearman's } \\
\text { rho }\end{array}$} & \multirow{3}{*}{ Supplication } & Correlation Coefficient & 1.000 & $.672^{* *}$ & $.664^{* *}$ & $.581^{* *}$ \\
\hline & & Sig. (2-tailed) & . & .004 & .000 & .001 \\
\hline & & $\mathrm{N}$ & 273 & 273 & 273 & 273 \\
\hline & \multirow{3}{*}{ Altruism } & Correlation Coefficient & $.672^{* *}$ & 1.000 & $.829^{* *}$ & $.608^{* *}$ \\
\hline & & Sig. (2-tailed) & .004 & . & .034 & .000 \\
\hline & & $\mathrm{N}$ & 273 & 273 & 273 & 273 \\
\hline & \multirow{3}{*}{ Sportsman } & Correlation Coefficient & $.664^{* *}$ & $.829^{* *}$ & 1.000 & $.765^{* *}$ \\
\hline & & Sig. (2-tailed) & .000 & .034 & . & .001 \\
\hline & & $\mathrm{N}$ & 273 & 273 & 273 & 273 \\
\hline & \multirow{3}{*}{ Conscient } & Correlation Coefficient & $.581^{* *}$ & $.608^{* *}$ & $.765^{* *}$ & 1.000 \\
\hline & & Sig. (2-tailed) & .001 & .000 & .001 & . \\
\hline & & $\mathrm{N}$ & 273 & 273 & 273 & 273 \\
\hline
\end{tabular}

**. Correlation is significant at the 0.01 level (2-tailed).

Source: SPSS output

i. Where the effect of supplication on altruism $=0.672$ at a $\mathrm{P}<0.05$. The null hypothesis is rejected based on the evidence of significance.

ii. Where the effect of supplication on sportsmanship $=0.664$ at a $\mathrm{P}<0.05$. The null hypothesis is rejected based on the based on the evidence of significance

iii. Where the effect of supplication on conscientiousness $=0.581$ at a $\mathrm{P}<0.05$. The null hypothesis is 
rejected based on the evidence of significance.

The results indicate that supplication as a form of leader impression management strategy significantly impacts and contributes towards organizational citizenship behaviour within the Tertiary Institutions. The evidence suggests that supplication has a high impact on both altruism and sportsmanship but contributes moderately towards conscientiousness. This describes the dimension as not only driving actions that can be described as unselfish and supportive within the organization, it also enhances a sense of comradeship within the organization. In this vein, it is evident that supplication is essential and improves the evidence of organizational citizenship behaviour within the organization.

\section{Discussion of Findings}

The relationship between supplication and the measures of organizational citizenship behaviour is observed to be significant. Where the test shows high effects of supplication on measures such as altruism (rho $=.672$ ), and sportsmanship (rho $=.664$ ), and a moderate effect of supplication on conscientiousness (rho $=.581$ ). The evidence indicates that there is a significant level of influence by supplication on the achievement of organizational citizenship behaviour in the Tertiary Institutions.

This agrees with the results of Kleinmann and Klehe (2011) and Jones (1990) which identified supplication as a strong tool which leaders can utilize to drive and enhance performance. Although its utility as Ellis and Wittenbaum (2000) emphasized is often considered most apparent especially when leadership is low on authority or disciplinary actions, nonetheless it is often adopted to appeal to the reason and conscience of subordinates as a way of convincing them about the need for performance or the expression of behaviours that are considered as necessary. Thus it is evident that through supplication, leaders can enhance organizational citizenship behaviour such as altruism, sportsmanship and conscientiousness in Tertiary Institutions in Port Harcourt.

\section{Conclusion and Recommendations}

The findings of this study affirm that supplication predicts organizational citizenship behaviour in Tertiary Institutions in Port Harcourt. That is to say that leaders who adopt the supplication leader's impression management strategy are bound to receive reciprocal gestures from subordinates who would go beyond their job requirement to exhibit behaviours that are discretionary and advantageous to the organization.

In line with the findings of this study, the following recommendations are made:

i. The use of supplication in leadership should enhanced as a way to increase the altruistic tendencies of subordinates.

ii. Supplication as a form of leader impression management should be encouraged as it impacts significantly towards organizational citizenship behaviour of sportsmanship.

iii. Though supplication strategy contributes moderately towards organizational citizenship behaviour of conscientiousness, leaders should endeavor to apply more of it in relating with subordinates.

\section{References}

Adler, P. S. \& Borys, B. (1996). Two types of bureaucracy: Enabling and Coercive. Administrative Science Quarterly, 41(March), 61-89.

Aiken, M. \& Hage, J. (1966). Organizational alienation: A Comparative Analysis. American Sociological Review, 31(August), 497-507.

Aziri, B, (2008). Job satisfaction: A literature review. Management Research and Practice. 3(4), 77-86.

Bass, B.M., \& Avolio, B.J. (1995). Multifactor leadership questionnaire, Mind Garden, Palo Alto, CA.

Bateman, T. S., \& Organ, D. W. (1983). Job satisfaction and the good soldier: The relationship between affect and employee citizenship. Academy of Management Journal, 26, 587-595.

Bhavnagar, J., (2005). The power of psychological empowerment as an antecedent to organizational commitment in Indian managers. Human Resource Development International, 8(4): 419-433.

Burke, C.S., Sims, D.E. Lassara E.H. \& Salas, E. (2007). Trust in leadership: A multi-level review and integration. Leadership Quarterly, 18(6): 606-632.

Cohen, A. \& Vigoda (2000). Do good citizens make good organizational citizens? An empirical examination of the relationship between general citizenship and organizational citizenship behaviour in Israel; Administration and society, 32(5), 596-625

Dirks, K. T., \& Ferrin, D. L. (2002). Trust in leadership: Meta-analytic findings and implications for research and practice. Journal of Applied Psychology, 87, 611-628

Dorothea. W. A. (2012). The relationship between social capital, organizational citizenship behaviors, and individual performance: An empirical study from banking industry in Indonesia, Journal of Management Research, 4(2).

Ellis, J. B., \& Wittenbaum, G. M. (2000). Relationships between self-construal and verbal promotion. Communication Research, 27(6), 704-722. 
Ertruk, A. (2007). Increasing organizational citizenship behaviours of Turkish academicians: Mediating role of trust in supervisor on the relationship between organizational justice and citizenship behaviours. Journal of Managerial Psychology, 22(3), 257-270.

Gabriel, J.M.O (2015). Organizational citizenship behaviour and corporate resilience in the domestic aviation sector of Nigeria. Unpublished PhD thesis. Rivers State University.

Jones, E.E. (1990). Interpersonal Perception. New York: W.H. Freeman and Company.

Jung, D., \& Avolio, B. (2000). Opening the black box: An experimental investigation of the mediating effects of trust and value congruence on transformational and transactional leadership. Journal of Organizational Behaviour, 21, 949-964

Kleinmann, M., \& Klehe, U.C. (2011). Selling oneself: Construct and criterion-related validity of impression management in structured interviews. Human Performance, 1, 29-46.

Lavelle, J. J. , D. E. Rupp \& J. Brockner, (2007). Taking a multi-foci approach to the study of justice, social exchange and citizenship behaviour: The target similarity model. Journal Management, 33: 841-866.

Marchington, M (2001). Employee involvement at work, in Storey J. (ed.). Human resource management: A critical text, 2nd ed., London, Thomson.

Miller, N. (2002). Insider change leadership in schools. International Journal of Leadeship in Education, 5, 343-360.

Organ, D. W. (1997). Organizational citizenship behaviour: It's construct clean-up time. Human Performance, $10,85-97$

Organ, D.W., P.M. Podsakoff \& S.B. MacKenzie, (2006). Organizational citizenship behaviour: Its nature, antecedents and consequences. Sage, London.

Parker, D.-J., \& Berger, B. K. (2004). The presentation of CEOs in the press, 1990-2000: Increasing salience, positive valence, and a focus on competency and personal dimensions of image. Journal of Public Relations Research, 16(1), 93-125.

Podsakoff, P. M., MacKenzie, S. B., Paine, J. B., \& Bachrach, D. G. (2000). Organizational citizenship behaviours: a critical review of the theoretical and empirical literature and suggestions for future research. Journal of Management, 26, 513-563.

Porter, M. E., \& Nohria, N. (2010). What is leadership? The CEO's role in large, complex organizations. In Nohria N. \& Khurana R. (Eds.), Handbook of leadership theory and practice (433-474). Cambridge: Harvard Business Press.

Rosenfeld,P., Giacalone, R. A., \& Riordan, C. A., (1995). Impression management in organizations. Theory, measurement, practice. Van Nostrand Reinhold.

Sandberg, J. \& Pinnington, A. H. (2009). Professional competence as ways of being: An existential ontological perspective. Journal of Management Studies, 46(7), 1138-1170.

Shokrkon,H \& Naami, A (2009). The relationship of job satisfaction with OCB and job performance in Ahvaz factory workers. Journal of Education and Psychology. 3(2), 39- 52.

Smith, C.A., Organ, D.W., \& Near, J.P. (2009). Organizational citizenship behaviour: Its nature and antecedents. Journal of Applied Psychology, 68(4), 653-663.

Turnipseed, D. L., \& Rassuli, A. (2005). Performance perceptions of organizational citizenship behaviours at work: A bi-level study among managers and employees. British Journal of Management, 16(3), 231-244.

Van Iddekinge, C. H., McFarland, L. A., \& Raymark, P. H. (2007). Antecedents of impression management use and effectiveness in a structured interview. Journal of Management, 752-773.

Wang H, Law K. S, Hackett R. D, Wang D, \& Chen Z. X (2005). Leader member exchange as a mediator of the relationship between transformational leadership and followers' performance and organizational citizenship behaviour. Academy of Management Journal, 48 (3): 420-432.

Wang, G., Oh, I. Courtright S.H. \& A.E. Colbert (2011). Transformational leadership and performance across criteria and levels: A meta-analytic review of 25 years of research. Group Organization Management, 36(2): $223-270$

Yaghoubi, N., Salehi, M., \& Moloudi, J. (2011). Improving service quality by using organizational citizenship behaviour: Iranian evidence. Iranian Journal of Management, 4(2), 79-97

Zarea, H.,( 2012). Organizational citizenship behaviors and their relationship to social capital in public organizations of Qom Province, Iranian Journal of Management Studies (IJMS).5,(1): 79-96 